\title{
Urban Aesthetics Analysis with Townscape Theory Approach in Architecture Photography (Case Study: Jakarta Old Town Core Zone)
}

\author{
Silviana Tahalea ${ }^{1}$, Erlina Novianti ${ }^{2}$, FX. Damarjati ${ }^{3}$ \\ \{silviana@trisakti.ac.id ${ }^{1}$ \} \\ Departemen of Photography in Faculty of Art and Design, Universitas Trisakti ${ }^{1}$, \\ Departemen of Photography in Faculty of Art and Design, Universitas Trisakti², \\ Communication Visual Design Program in Universitas Matana ${ }^{3}$
}

\begin{abstract}
Urban esthetics is an important aspect that must be recognized and understood, especially the ones related with urban architecture and/or urban design. Along with the history of an urban area, activities to identify esthetic aspects must be implemented in order to improve urban esthetic value created by certain spaces in the urban area. One aspect that can be conducted to analyze urban area morphology is by implementing analysis on an area or an urban area through its products. One general approach to analyze urban area product is through City Imaging and Townscape. Architecture photography can be utilized to document elements of a building, both in general and in details while also focuses on urban esthetics. Urban esthetics value is a tool to identify an urban area, and act as a vital element to describe the dynamic aspect of an urban area. One of the most interesting areas in Jakarta to be analyzed is the old town core zone area as an appealing area to be visualized based on townscape theory due to its historic buildings and as one of the leading cultural tourism destination pillars located in DKI Jakarta. This utilizes qualitative research method, which is a method to explore various phenomenon bound by time and activity, through detailed data and information gathering by using photographical approach. The result of this research revealed that Old Town core zone still requires a number of improvements to be developed into an area that fulfill Urban Esthetic concept.
\end{abstract}

Keywords: Urban Esthetics; Architectural Photography; Townscape; Old Town Jakarta

\section{Introduction}

Technological advances have facilitated, accelerated, and provided the ability for photographers to experiment, which eliminate time and cost problems. Along with the development of photographical media, for example camera technology, the quality of architectural photos also experiences linear improvements. Architectural photography which initially focuses on buildings have become broader and developed into landscapes and urban 
photography. To produce decent architectural photos, the right exposure and composition are vital. The general composition in architectural photography is the rule of third and golden ratio. Both of these compositions are relatively easy and enable photographers to produce more stand out, balanced, and more interesting photos [1].

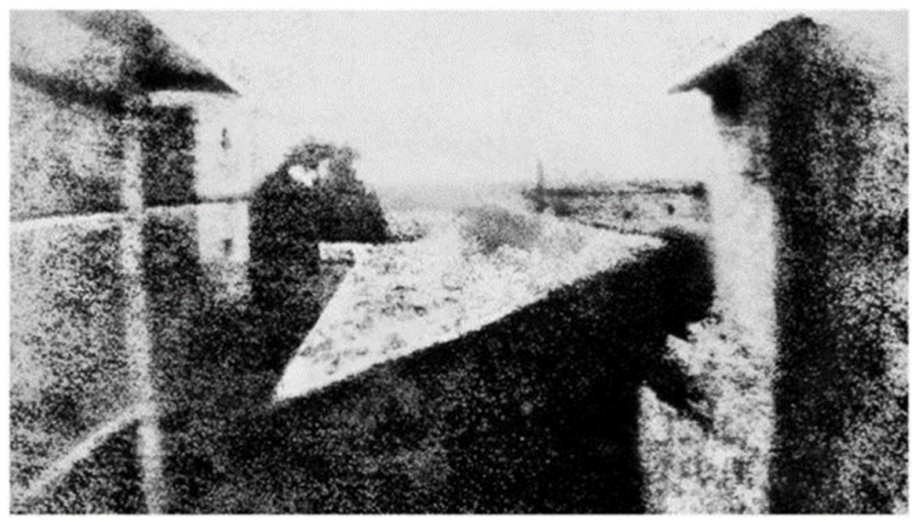

Fig. 1. View from the window by Joseph Nipche 1826.

Source: https://www.thevintagenews.com/2019/01/14/firsts-in-photography/

Architectural photography can be used to document the elements of a building, both as a whole and in detail, as well as talk about the aesthetics of an urban area. Urban aesthetics is one tool to identify an urban area, it is an element that is needed to see the dynamics of an urban area [2]. To assess the beauty of an urban area, not only to judge the architectural style, the buildings, there are other things to consider, such as traffic and noise effects, social and historical features which are a unified sensory package that must be taken into account in assessing the beauty of an urban area. As for the things outside of those benchmarks, the valuation is determined by the number of awards or predicates accepted by the urban area.

Aspects of the beauty of the urban area or the urban esthetic is an important aspect that must be recognized and understood, especially those related to urban architecture or urban design. Along with the history of an urban area, activities to identify aspects of the beauty of the urban area must be carried out with the aim of improving the urban esthetic aspects of certain areas in an urban area. In the down town area, because the urban area center is usually an area that is strategically located and has high social and economic value, efforts to improve the beauty aspect of the area must be made. The purpose of efforts to improve the urban esthetic is to support the development of urban area in order to be able to: (a) expose its visual appeal or beauty, (b) exhibit its attraction regarding tourism activities, and (c) emphasize its distinctive and unique spatial characteristics.

One way to analyze urban area morphology is by emphasizing the focus on a specific area or by paying attention to its products. To analyze a city through its products approach can be implemented by acknowledging its product in form of the city's physical form through city imaging or Townscape. Townscape is an art that is able to visualize building, street and spatial structures that decorate urban areas. The townscape concept act as a basic for the architects and city planners. The physical form of an urban area is influenced and determined by the shapes and masses of the buildings. Through a book titled The Concise Townscape, Gordon Cullen presents a number of values that must be implemented on urban design in order to form both psychological and physical emotional attachment on the people. 
One interesting area in Jakarta to be analyzed is the core zone of old town area. This area is appealing to be visualized into townscape theory due to its historical buildings and as one of the leading pillars of tourism area in DKI Jakarta. Old Town area in Jakarta is a unique historical heritage by utilizing architectural photographic media, author will produce urban esthetic pattern analysis based on Gordon Cullen's townscape theory. The result will determine whether the area can be categorized as comfortable and esthetic residential area for the people. Author limits the research area at Old Town area in Jakarta because due to its colonial history and high quality traditional European esthetical design to accommodate human needs, and to measure whether the design is suitable for the people of DKI Jakarta.

\subsection{Old Town Area in DKI Jakarta}

In 1527, Fatahilah (The Sultan of Demak) invaded Sunda Kelapa area which was governed by The Portugal, and succeeded to reclaim the area and change its name into Jayakarta. After the victory, numerous Dutch vessels arrived at Jayakarta to conduct commercial businesses. On the $16^{\text {th }}$ century, The Dutch and English people are allowed to build warehouses to fulfill their trading requirements in Sunda Kelapa. On the $17^{\text {th }}$ century, Dutch movements in the area was getting wider and they started to build forts equipped with cannons and also started to eliminates indigenous people from the area, which lead to a war between the Dutch and the indigenous people. The war was won by the Dutch which later claimed Jayakarta and change its name into Batavia. The Dutch with its multinational company, VOC, developed a number of trading activities because Batavia was used as a port city.

Batavia city design was highly influenced by ideal and practical theories as referred by Stevin, a Dutch expert in urban planning in the $17^{\text {th }}$ century. According to his theory, a church is an important part of European cities, because it can bind God and human. An urban area should also possess military defense and commercial functions. In its ideal concept, Stevin includes public and residential areas, canals, and box grids to protect public areas without eliminating individual freedom. Besides that, canal act as important part of colonial cities development. Public buildings such as castles, churches, schools, hospitals, markets and sojourns for foreign merchants were arranged in such way to avoid dominance between one and another and to avoid impression of abandonment. The effort was conducted by placing these buildings on elongated axis on one and both sides/parts of the city.

\subsection{Urban Aesthetics}

The terminology of urban design is very diverse, and many experts have suggested what urban design is. According to Jan Gehl [3] urban design is if the interaction between humans and architectural dimensions becomes dynamic. Social interactions, perceptions, urban recreation and sensory experiences take place in city life. According to Cullen [4] urban design is about how an urban plan can affect the emotional perception of people living in the city, how urban elements should be able to make the quality of life of urban people better.

The phenomenon of the formation of urban areas or the urban areas phenomenon has resulted in several important things that become the center of our attention. The important matters referred to include: (a) for the future urban areas (urban areas) are becoming increasingly important to pay attention to due to the intensity of development activities, (b) development activities in urban areas are becoming more dominant and have a high socioeconomic value compared to rural areas, (c) the condition of people in urban areas is becoming interesting from an urban sociology perspective, and (d) symptoms of urbanism in 
urban communities are becoming increasingly important. associated with the demands for the quality of life of urban people who are getting higher. An important influence in dealing with the phenomenon of the formation of urban areas is the increasingly strategic urban planning activities. Urban aesthetics has the goal of creating a space that is not only functional but also can increase the productivity of the community at the same time, besides that the comfort and historical value of the city are also maintained.

\subsection{Townscape Theory}

According to Gordon Cullen [4] Townscape is an art that is visually contained in the arrangement of buildings, roads, and spaces that adorn the urban environment. Another definition of townscape is a way that can be used in terms of physical visuals to identify the physical form of a city. In addition, the townscape can also be identified through the form of arrangement or design of buildings and roads that are captured based on the various emotional levels of each observer. This townscape concept is the basis for architects, planners, and parties who pay attention to the face of the city. The physical form of urban space is influenced and determined by the shape and mass of the building. This connection is felt psychologically and physically by observers of the physical form of urban space and the shape and mass of the building. In addition, the relationship can also be seen visually in the quality of the shape of the city which is determined by the shape and size of the city space and its arrangement. The four elements that make up townscape that Cullen emphasizes in his book are:

\section{a) Serial Vision}

Serial vision are visual images captured by observers that occur while walking from one place to another in an area. Recorded views by the observer into pieces of the image gradually and form a unified image recording area for the observer. Usually, there will be a resemblance, a common thread, or a marker of the pieces of view that give certainty to the observer that he is still in the same area.
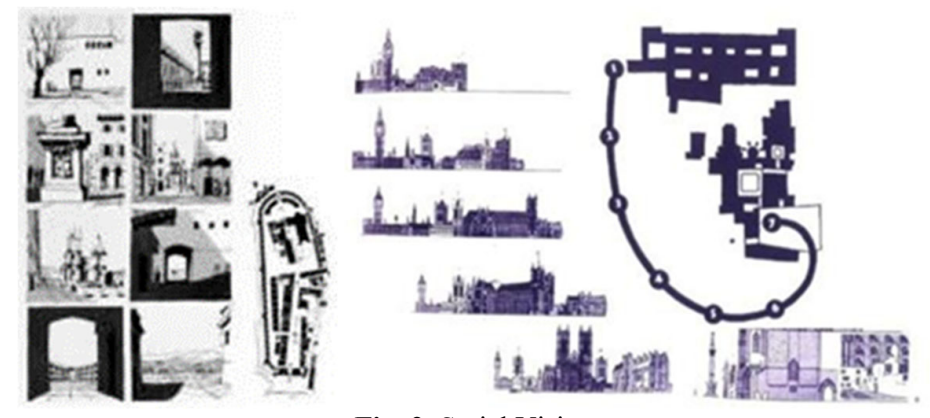

Fig. 2. Serial Vision Source: Cullen [4]

\section{b) Place}

Place is the feeling the observer has emotionally when he is in a certain place. Place is influenced by the boundaries that exist in that place. Place can also help observers develop 
ideas about a sense of place and ownership of a place but which cannot be fully defined and articulated.

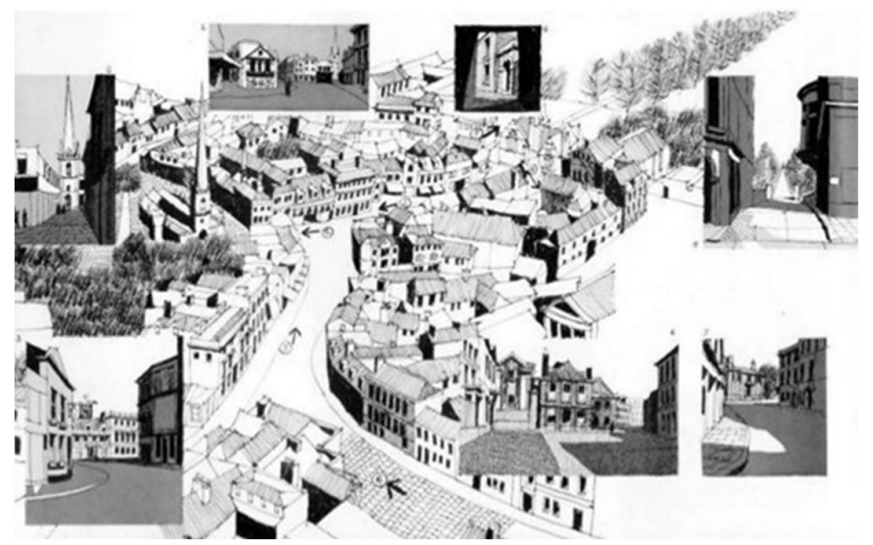

Fig. 3. Place

Source: Cullen [4]

\section{c) Content}

Content is the content of an area that affects one's feelings about the state of the city's environment. Content depends on two factors, namely on the level of conformity and depends on two factors, namely on the level of conformity and the level of creativity. This topic deals with the physical appearance of fabrics in terms of color, texture, character, style, scale and uniqueness. Content also talks about the concept of "Seeing in Detail" this can be observed through, the placement of different buildings with variations in size and height is considered as a form of detail. On the other hand, the existence of multi-use buildings that make up a community is a concept that should be examined by topic of content. Content refers to the aesthetics of a place containing visual organization through "color, texture, scale, style, character, personality, and uniqueness".

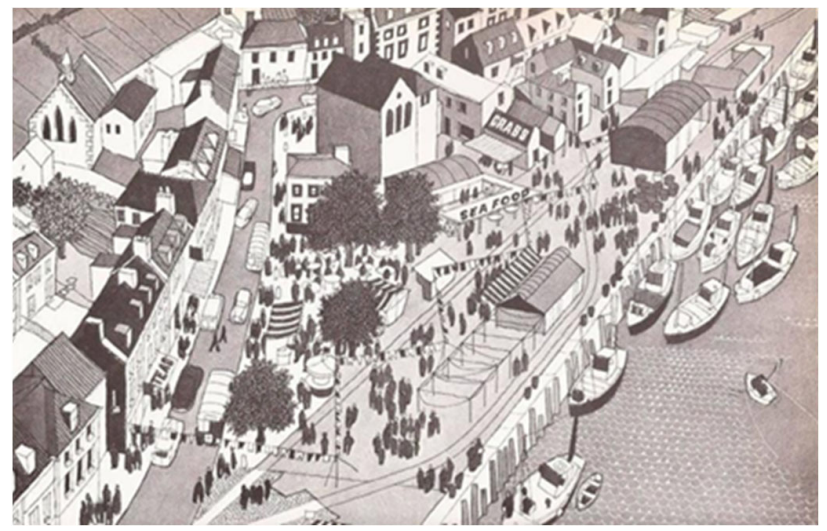

Fig. 4. Place

Source: Cullen [4] 


\section{d) The Functional Tradition}

The functional tradition is the quality in the elements that make up the urban environment which also has economic, efficient and effective aspects. The functional tradition also talks about the intrinsic qualities of the elements that make up a man-made landscape such as crossroads, the intersection of two paths, the end point of an area, floor plans, etc.

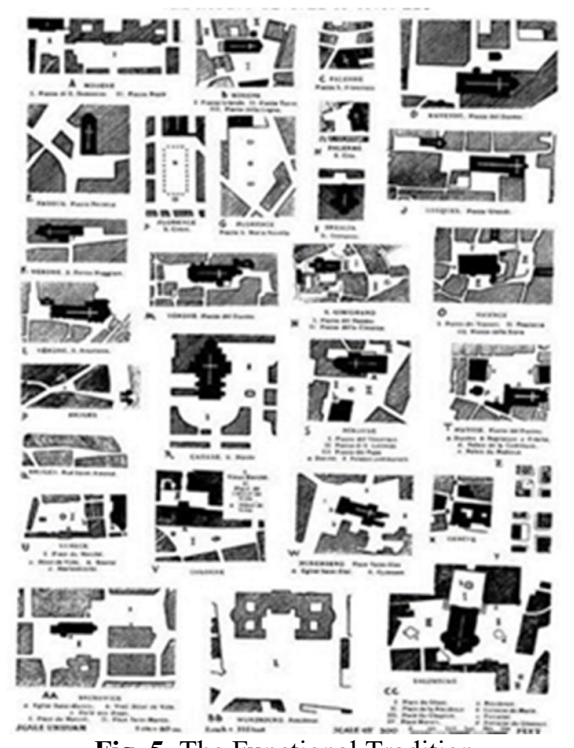

Fig. 5. The Functional Tradition Source: Cullen [4]

Based on these four elements, Townscape functions to see the identity and meaning of urban area design, to recognize its physical condition, to identify forms that characterize it through buildings and roads arrangement captured through various emotional levels of each observer.

\section{Method}

In this research, the type of research used by the author is case study research, this is a type of qualitative research in which the researcher explores phenomenon bound by time and activity, and to collects detailed information and data using photography as an approach within a certain period of time [5], [6]. In this study, the author will collect field data by photographing parts around Old Town of Jakarta as a case study location, using an architectural photography approach, with reference to aesthetic elements that are in accordance with townscape theory, this townscape theory can be used to analyze whether the elements of a city meet the aesthetic value of the city so that it can make people who live in the city feel comfortable. 


\section{Results and Discussion}

Table 1. Analysis of Town Scape

\begin{tabular}{ll}
\hline $\begin{array}{l}\text { Town } \\
\text { Scape }\end{array}$ & \multicolumn{1}{c}{ Analysis } \\
\hline Serial & $\begin{array}{l}\text { The vision series in the Old Town Core } \\
\text { Zone shows the shape of the Dutch heritage } \\
\text { building which until now still stands strong } \\
\text { and continues to be revitalized and well } \\
\text { maintained by the Jakarta City } \\
\text { Government, namely the Fatahillah } \\
\text { Museum; this museum is very iconic as a } \\
\text { tourist destination in Jakarta. The serial } \\
\text { vision in this picture shows the process of } \\
\text { the observer's journey to the Fatahillah } \\
\text { Museum. On the left, we can see the side of } \\
\text { the Batavia café, which is one of the } \\
\text { culinary centers in Old Town, which is also } \\
\text { one of the economic centers in the Old } \\
\text { Town area. Chacteristically, this area still } \\
\text { has a very strong colonial feel and its } \\
\text { beauty is still well preserved. }\end{array}$ \\
\end{tabular}

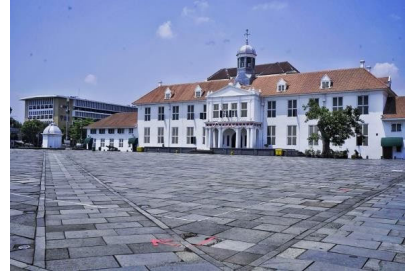

Fig. 6. Serial Vision Source: Silviana Tahalea [7]

\section{Place}

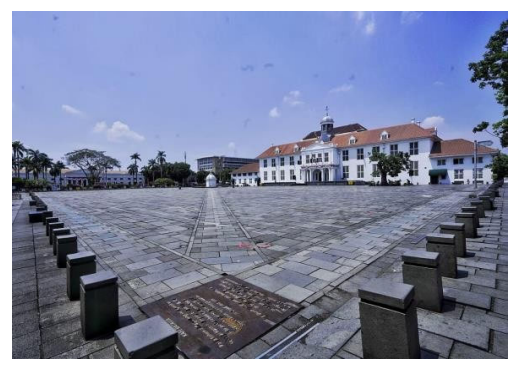

Place is an area or place that can emotionally arouse the feelings of the observer. The open field in front of the Fatahillah Museum is an element of place because usually in a large field surrounded by this magnificent colonial building, observers can imagine how life was in the colonial era, apart from the buildings that are still well preserved, the local government continues to revitalize this location. In terms of elements of urban aesthetics, this place is an area that can increase the economic potential of the city. Because this place is one of Jakarta's tourist destinations and there are lots of restaurants or shops selling handicrafts, besides that, there are also many street vendors who have been arranged by the old city manager 


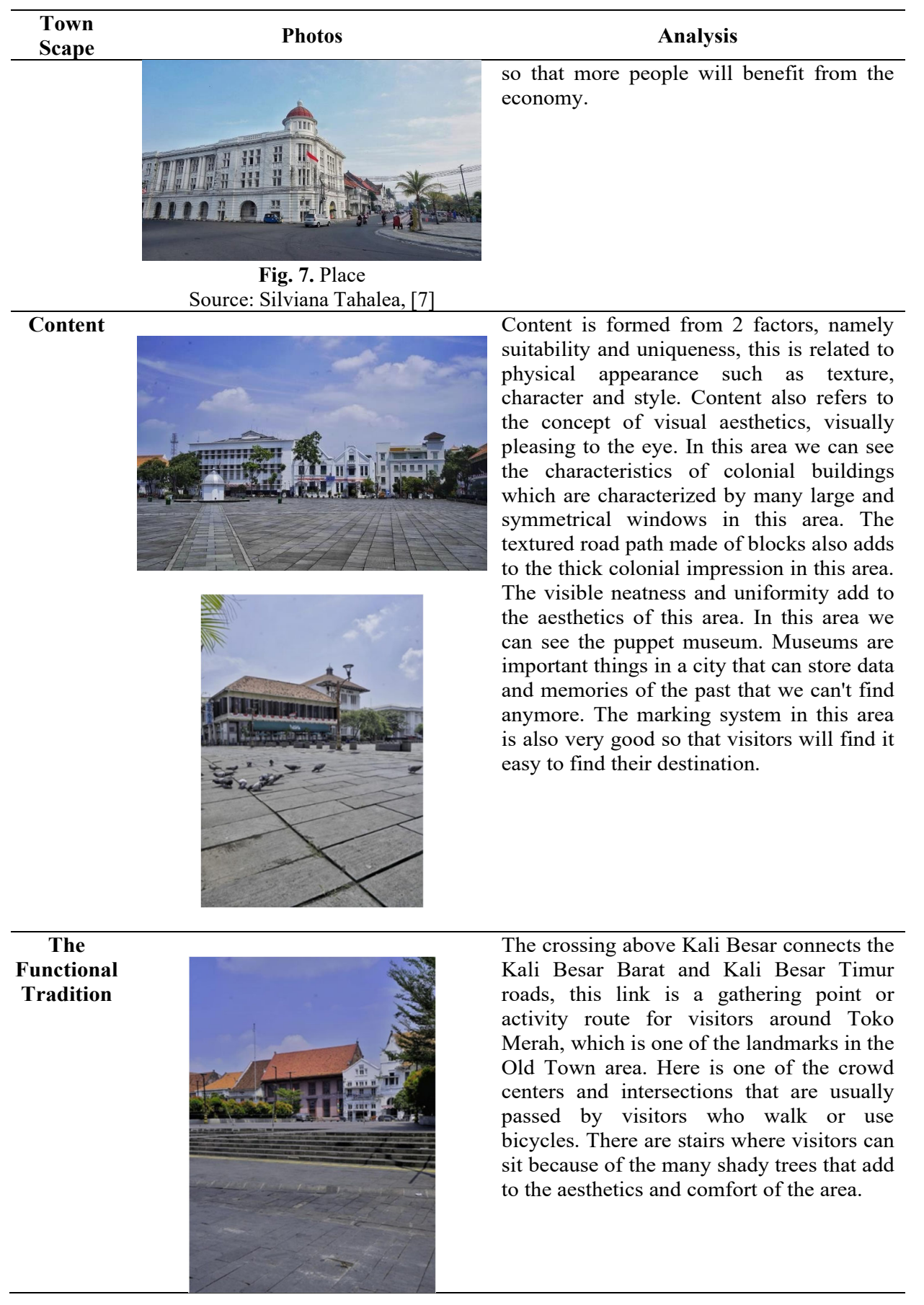




\begin{tabular}{ccc}
\hline $\begin{array}{c}\text { Town } \\
\text { Scape }\end{array}$ & Photos Analysis \\
\hline & Fig. 8. The Functional Tradition \\
Source: Silviana Tahalea [7]
\end{tabular}

\section{Conclusion}

Based on the result of this research, we determined that the conclusions are as follows:

1. As an area developed under Dutch colonial urban planning, the Old Town Core Zone is still very thick with colonial architecture. There are a number of well-preserved parts, but there are also areas that are not so well-maintained with the emergence of new buildings.

2. Colonial characteristic of the Old Town Core Zone area can be seen by its large columns and square layouts. Ornaments such as street pavements, street decoration and lamps are adapted to the colonial characteristics.

3. Based on urban esthetics perspective which emphasize that a decent urban area is an area with dynamic economy activities, Old Town area is already categorized as a well dynamic area based on economic perspective due to the existence of giftshops, craft shops, food courts, and museums.

4. Based on urban esthetics perspective regarding comfort level, with the high volume of litters it is difficult to achieve high level of comfort. The indecision of the local government regarding commercial areas invites street vendors to carelessly use areas which is initially prohibited, this has lowered esthetics beauty of the area.

5. Based on esthetics perspective regarding comfort level, this area is also quite comfortable to be visited and inhibited due to availability of different public transportation facilities and wide roads that are able to contain high volume of vehicle. However, the traffic signs should be revitalized on a number of areas. The lack of directional signs has made it difficult for the tourists to determine the right directions. Traffic signs are not well maintained, which is shown by faded zebra cross and unfunctional pedestrian crossing lights. This has lowered the comfort level of the tourists.

6. Based on esthetics perspective regarding public open spaces, Old Town Core Zone provides abundant open spaces and general facilities. There are numerous seating areas to rest and plants that add beautifulness to this area.

\section{References}

[1] A. Schulz, Architectural Photography. Santa Barbara. California: Rocky Nook Inc, 2015.

[2] R. J. Sternberg dan T. I. Lubart, "An investment theory of creativity and its development," Hum. Dev., vol. 34, no. 1, hal. 1-31, 1991.

[3] J. Gehl, "Cities for People," J. Archit. Plann. Res., vol. 29, no. 2, hal. 172-174, 2012. 
[4] G. Cullen, The Concise Townscape. London: The Architectural Press, 1961.

[5] J. W. Creswell, Research design: Qualitative and quantitative approaches. Thousand Oaks, CA: SAGE Publications, 1994.

[6] P. Leedy dan J. Ormrod, Practical research: Planning and design, 7 ed. Upper Saddle River, NJ: Merrill Prentice Hall, 2001.

[7] S. Talahea, "Research Documentation." 2020. 